8

9

\section{synthesis of bioplastics}

\author{
D. Beneroso, J.M. Bermúdez, A. Arenillas, J.A. Menéndez* \\ Instituto Nacional del Carbón, CSIC, Apartado 73, 33080 Oviedo, Spain \\ * Corresponding author. Tel.: +34 985 118972; Fax: +34 985297672 \\ E-mail address: angelmd@incar.csic.es
}

\title{
Abstract
}

In this article we propose the possibility of obtaining syngas from very different and complex organic wastes, such as municipal solid wastes, agricultural residues or sewage sludge, through microwave-induced and conventional pyrolysis at 400 and $800{ }^{\circ} \mathrm{C}$. Microwave heating has proved to be an appropriate way to produce a syngas with $\mathrm{CO}+$ $\mathrm{H}_{2}$ concentrations as high as 90 vol.\% and in large yields (up to $0.83 \mathrm{~L} \mathrm{~g}^{-1}$ waste). In addition, the potential of the syngas produced by this technology as fermentation substrate for the production of bioplastics is discussed. Microwave pyrolysis seems to serve as a novel route into biorefineries to produce valuable biobased products.

\section{Keywords}

Bioplastics, Polyhydroxyalkanoates, Syngas fermentation, Microwave pyrolysis, Waste valorization 


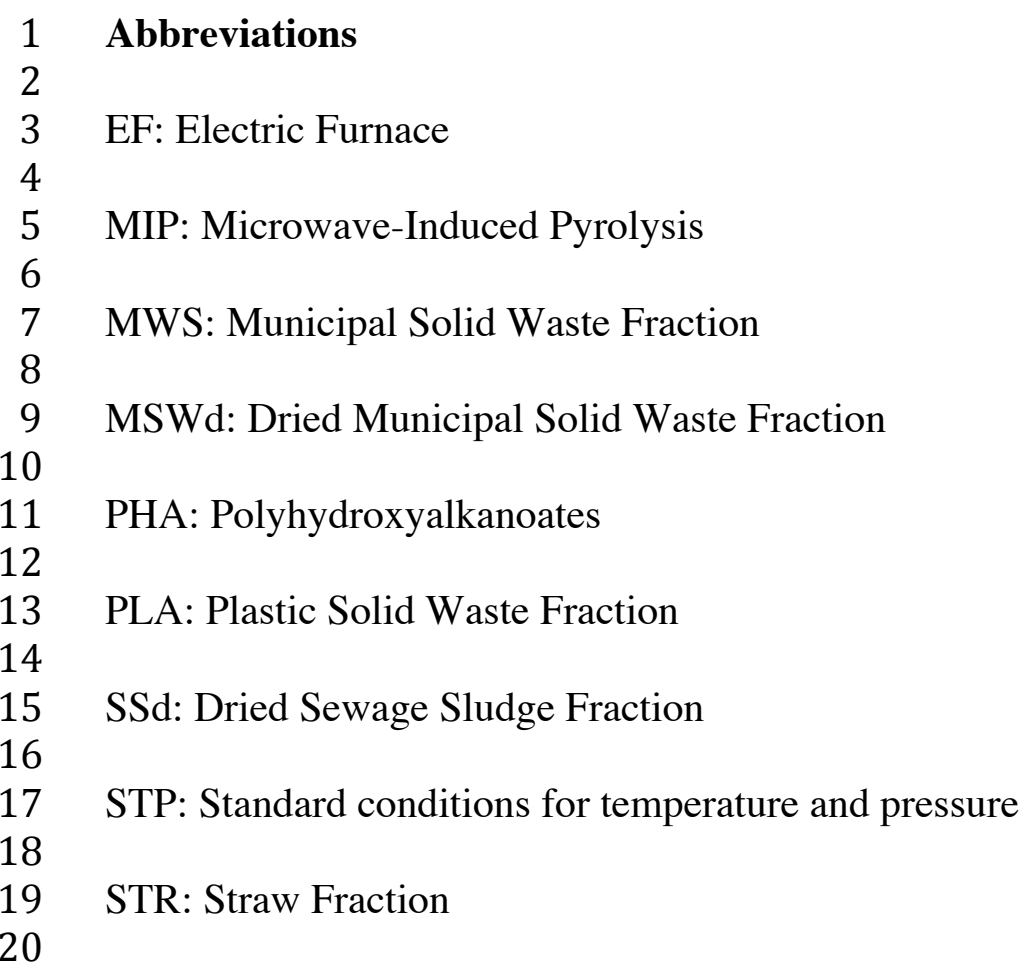


1

2

3 Plastics are widely used in almost all industries, especially in the packaging and

4 building sectors, due to their great versatility, low weight and excellent electrical and

5 thermal insulation properties. Although the production of plastics has grown worldwide

6 since 1950, in the European Union, this production has remained practically constant at

$7 \quad 55-60$ million tons per year since 2000 . The production process leads inevitably to the

8 generation of large amounts of plastic waste. The slow degradation rate, the potential

9 risk of accidental fire and the heavy metals content in plastic additives have been

10 proposed as the potential reasons for the search for alternative means of disposal to

11 landfill, such as re-extrusion, mechanical recycling, chemical recycling or energy

12 recovery $[1,2]$. The increasing use of these technologies has led to a decrease in the

13 amount of waste plastic sent to landfill sites since 2008. Alternatively, because of the

14 finite sources of fossil reserves, bioplastics production is a niche industry that is being

15 developed in an attempt to overcome the non-degradability problem of fossil-based

16 plastics, and to help reduce the carbon footprint of products [3,4]. According to

17 European Bioplastics (http://en.european-bioplastics.org/), bioplastics are economically

18 innovative and have great potential for further economic growth along the value added

19 chain.

20

21 Of special interest are those plastics that are biobased and biodegradable, such as

22 polyhydroxyalkanoates [5] (PHA), which can be employed for short-life applications

23 such as packaging [6], certain agricultural applications [7] and bags suitable for organic

24 recycling, although more sophisticated uses of PHA have also recently been reported

25 (tissue repair and regeneration, drug delivery systems or heart tissue engineering) $[8,9]$. 
1 Since PHA are polyesters with a highly versatile structure, their potential is immense.

2 Their thermo-mechanical properties can even be tailored to make them comparable to

3 those of conventional plastics $[10,11]$. PHA can be made by causing microorganisms to

4 accumulate them. High-value substrates such as sucrose, methanol or vegetable oils can

5 then be subjected to fermentation and converted into PHA. However, the cost of these

6 carbon sources, which may amount to as much as $50 \%$ of the total production cost of

7 PHA, is the main reason for the slow growth of the PHA industry [12]. For this reason,

8 the use of cheaper renewable resources as substrates such as wastes from biodiesel

9 production [13], waste plant oils [14], paper industry wastewater [15] or dairy

10 wastewater activated sludge [16], is essential to ensure the commercial viability of the

11 process. Another attractive alternative would be to use syngas, defined for this

12 particular application as $\mathrm{CO}+\mathrm{H}_{2}+\mathrm{CO}_{2}$. Syngas fermentation has been proposed as a

13 conversion route to produce bulk chemicals such as ethanol [17], acetate [18] or

14 butyrate [19]. The use of syngas fermentation affords significant advantages over

15 conventional processes for producing such chemicals as shown in Table 1.

17 Even though more than 300 microorganisms are known to synthesize PHA [20], few of

18 them are able to process the syngas components [21]. For instance, autotroph

19 microorganisms can use single-carbon compounds $\left(\mathrm{CO}\right.$ and/or $\left.\mathrm{CO}_{2}\right)$ as their sole carbon

20 source and $\mathrm{CO}$ and $\mathrm{H}_{2}$ as their energy source whereas unicarbonotroph microorganisms

21 are only able to use CO directly as their sole source of both carbon and energy. The use

22 of syngas as substrate to produce PHA is a truly novel research area, and this explains

23 why so little information is available. Do et al. studied the growth of Rhodospirillum

24 rubrum on seed corn-derived syngas containing $8.8 \% \mathrm{H}_{2}, 17.2 \% \mathrm{CO}$ and $16.3 \% \mathrm{CO}_{2}$,

25 which resulted in a mixture of two types of PHA ( $\beta$-hydroxybutyrate and $\beta$ - 
1 hydroxyvalerate) [22]. According to these authors, small quantities of $\mathrm{H}_{2} \mathrm{~S}$ in the syngas

2 may have been responsible for increased growth rates. The results of their research were

3 used to develop a techno-economic model to demonstrate the feasibility of PHA

4 production from biomass-derived syngas fermentation [23]. It is with this aim that the

5 SYNPOL project (http://www.synpol.org) is currently being developed and is expected

6 to enable the European Union to lead the way in the field of syngas fermentation

7 technology for waste valorization and sustainable biopolymer production.

8

9 Table 1. Advantages and drawbacks of using syngas in biocatalytic processes.

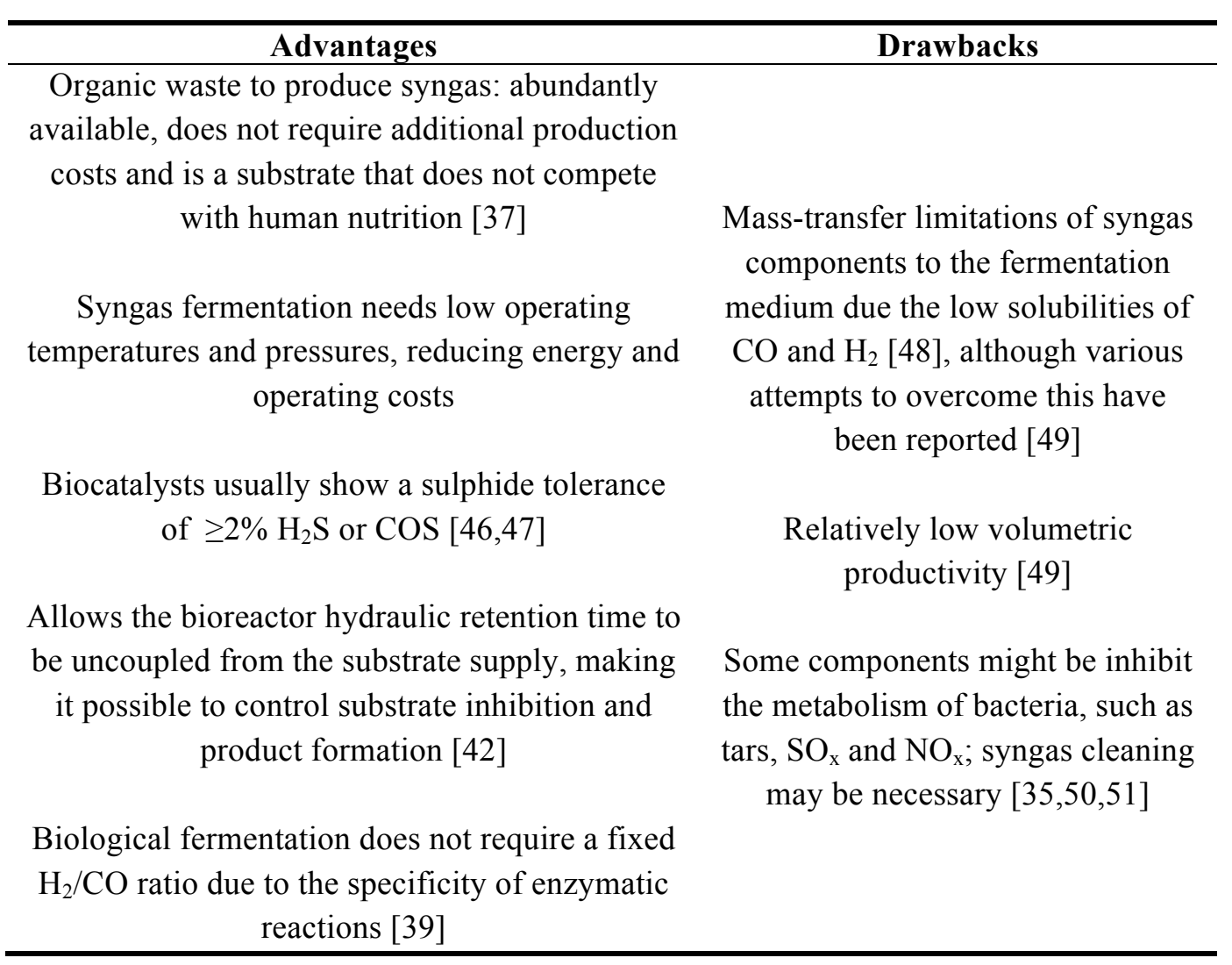

13 We propose a new potential bioprocessing scheme in Fig. 1 for the production of

14 biodegradable polyhydroxyalkanoates. As shown, the syngas stream can be obtained

15 from renewable feedstock. The microwave pyrolysis of biomass has demonstrated its 16 potential to maximize both the gas yield and syngas concentration, and so is the most 
1 appropriate heating method to obtain syngas for fermentation [24-29]. This process

2 prevents the generation of wastes, e.g. by recirculating part of the solid char to the

3 reactor as a microwave receptor material [28]. The microwave heating mechanism is

$4 \quad$ volumetric and yields quite different product distributions by favoring heterogeneous

5 reactions between the volatiles released and the carbonaceous waste. This makes it

6 possible to increase the concentration of valuable products, such as $\mathrm{CO}$, for bioplastics

7 production. In short, microwave pyrolysis offers an excellent opportunity for diverting

8 organic waste away from the traditional disposal methods such as landfill and

9 incineration and the possibility of recovering commercially valuable products from

10 wastes. Besides, the use of microwave pyrolysis to produce syngas on a large scale will

11 probably contribute to a more environmentally sustainable and energy-efficient process

12 compared to conventional heating processes, as has been demonstrated in a recent study

13 in which energy efficiency of microwave pyrolysis of wheat straw was 1.5 times higher

14 than the energy efficiency achieved by a conventional pyrolysis process [30]. Although

15 this technology has been widely studied, it has never been previously proposed for the

16 production of syngas for use in fermentation processes. Moreover, no studies have yet

17 explored the possibility of applying microwave-induced pyrolysis to the biopolymer

18 production process through syngas fermentation. Once the syngas is fermented by

19 bacteria, PHA can be recovered by using a solvent extraction; e.g., using chloroform

20 and methanol [31] or combining surfactant addition to break down the cell wall

21 followed by solubilization of cell material with sodium hypochlorite [23]. This stage

22 should be followed by the separation of the PHA-containing phase from the residual

23 cell material by sedimentation.

24 


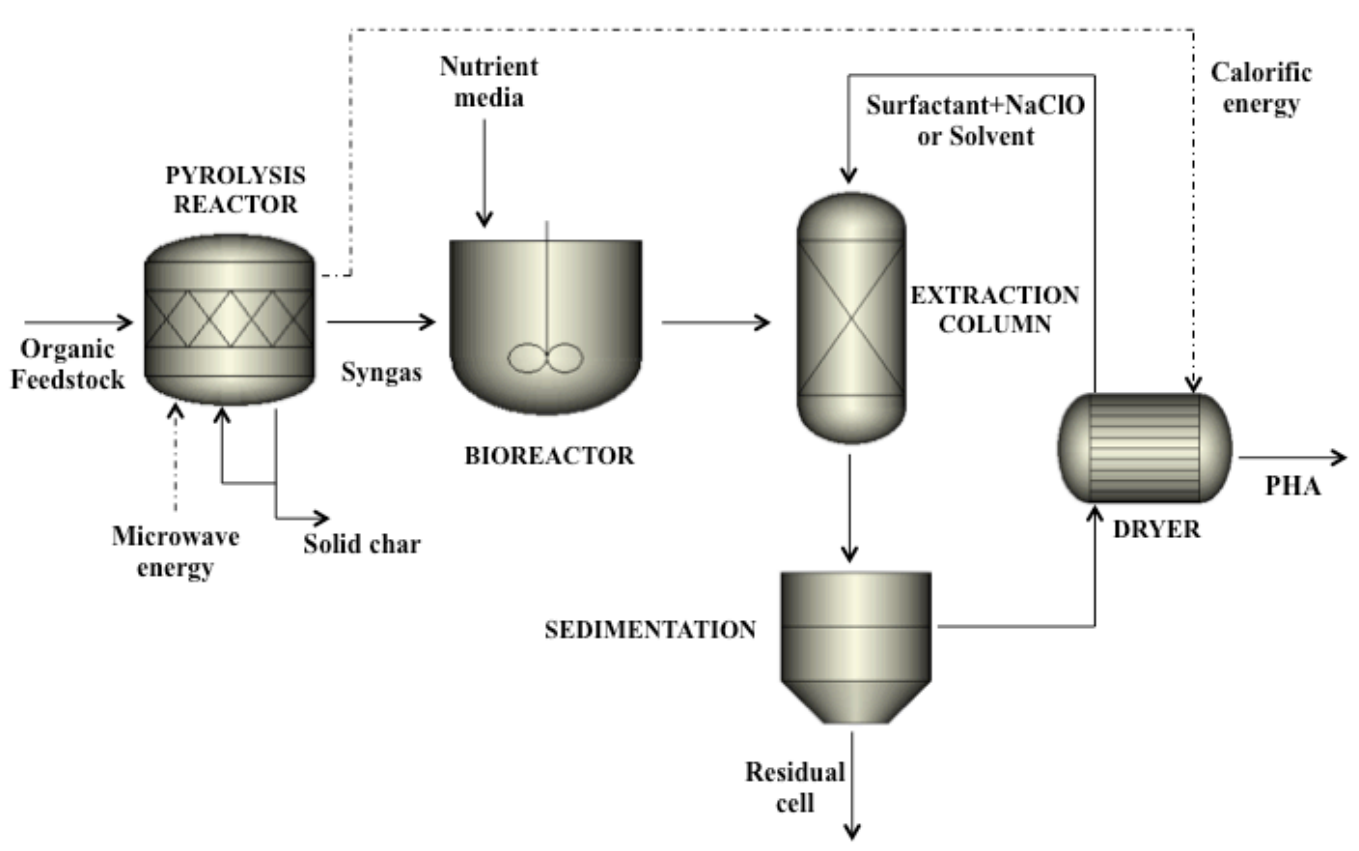

1

5 In this article we offer an extensive comparative study of organic wastes and their

6 pyrolysis-derived syngas at different temperatures and in two different heating systems

7 for their subsequent use as feedstock for bioplastics production by means of syngas

8 fermentation. Of particular interest is the innovative use of microwaves to achieve this

9 goal, as this possibility to the best of our knowledge has never been considered before 10 in the literature.

11

\section{2. Material and methods}

\section{$14 \quad$ 2.1 Samples preparation}

16 Five different samples, provided by BEFESA Gestión de Residuos Industriales S. L.

17 (Seville, Spain), were selected for this study: 
22 The moisture, ash content and volatile matter data of the residues were obtained by 23 means of a LECO TGA-601. To perform the ultimate analysis, a LECO-CHNS-932 24 micro-analyzer and a LECO-TF-900 furnace were used. The micro-analyzer provides 25 carbon, hydrogen, nitrogen, and sulfur percentage composition. The oxygen content was

1. An organic fraction from a municipal solid waste, obtained from a landfill in Seville (Spain). This fraction was subjected to a size reduction of 1-3 $\mathrm{mm}$. This sample will be labelled as MSW.

2. An organic fraction from a municipal solid waste, dried and partially cleaned from inerts. This fraction was taken from the previous fraction (MSW) and subjected to removal of moisture and inert solids, such as glass or metals. After this pre-treatment, the fraction size was reduced to 1-3 $\mathrm{mm}$. This sample will be labelled as MSWd.

3. A plastic fraction from a municipal solid waste. This sample, a complex mixture of plastic residues, was obtained from the same landfill in Seville. The fraction was milled to 1-3 mm and will be labelled as PLA.

4. An agricultural residue. This sample was obtained from a biodiesel production plant located in Salamanca (Spain) and is composed of straw. The sample was also milled to a size range of 1-3 mm. This sample will be labelled as STR.

5. Dried sewage sludge. This sample was collected from a wastewater plant in Seville. The sludge after being subjected to secondary treatment was dried to facilitate transportation. After being dried, the sample was milled to a size range of 1-3 mm. This sample will be labelled as SSd.

\subsection{Analysis of the samples}


1 determined from the LECO-TF-900 furnace. The content of metals from the ashes was

2 determined by means of atomic absorption spectroscopy using an Agilent 7700x. The

3 results from this characterization are presented in Table 2. The TGA and DTGA profiles

4 were obtained using a SDTQ600 Thermobalance (provided by TA Instruments) using a

5 flowrate of $\mathrm{N}_{2}$ of $20 \mathrm{~mL} / \mathrm{min}$ with a heating rate of $10{ }^{\circ} \mathrm{C} / \mathrm{min}$ up to $1000{ }^{\circ} \mathrm{C}$. The

6 thermogravimetric behavior of the residues is shown in the Supplementary Data (see

$7 \quad$ Fig S1-S5).

8

9 Table 2. Proximate and ultimate analyses of the different residues. Content of metals of 10 the ashes.

\begin{tabular}{|c|c|c|c|c|c|c|}
\hline \multicolumn{2}{|l|}{ Residue } & $\begin{array}{c}\text { Municipal } \\
\text { solid waste - } \\
\text { Organic } \\
\text { fraction }\end{array}$ & $\begin{array}{c}\text { Municipal } \\
\text { solid waste - } \\
\text { Dried\&Clean } \\
\text { organic } \\
\text { fraction } \\
\end{array}$ & $\begin{array}{c}\text { Municipal } \\
\text { solid waste - } \\
\text { Plastic } \\
\text { fraction }\end{array}$ & Straw & $\begin{array}{c}\text { Sewage } \\
\text { sludge (dried) }\end{array}$ \\
\hline \multicolumn{2}{|l|}{ Label } & MSW & MSWd & PLA & STR & $\mathrm{SSd}$ \\
\hline \multirow{3}{*}{$\begin{array}{l}\text { Proximate } \\
\text { analysis } \\
(w t . \%)\end{array}$} & Moisture & 46.3 & 2.8 & 1.3 & 11.5 & 3.4 \\
\hline & $\mathrm{Ash}^{\mathrm{a}}$ & 22.6 & 27.7 & 8.9 & 6.3 & 15.4 \\
\hline & $\begin{array}{l}\text { Volatile } \\
\text { matter }^{\mathrm{a}}\end{array}$ & 68.0 & 61.1 & 88.9 & 76.2 & 74.5 \\
\hline \multirow{5}{*}{$\begin{array}{l}\text { Ultimate } \\
\text { analysis } \\
\text { (wt.\%) }\end{array}$} & $\mathrm{C}$ & 36.0 & 45.1 & 70.9 & 45.0 & 43.8 \\
\hline & $\mathrm{H}$ & 5.8 & 5.4 & 9.7 & 5.0 & 6.1 \\
\hline & $\mathrm{N}$ & 1.6 & 2.1 & 1.2 & 1.6 & 9.7 \\
\hline & $S$ & 0.2 & 0.4 & 0.5 & 0.0 & 0.1 \\
\hline & $\mathrm{O}$ & 33.8 & 19.3 & 9.1 & 42.0 & 24.9 \\
\hline \multirow{9}{*}{$\begin{array}{l}\text { Content of } \\
\text { metals } \\
(\text { ppm) }\end{array}$} & $\mathrm{Cu}$ & 24.6 & 44.8 & 50.8 & 0.00 & 153.4 \\
\hline & $\mathrm{Cd}$ & $<0.1$ & $<0.1$ & $<0.1$ & 0.41 & 2.0 \\
\hline & $\mathrm{Mn}$ & 13.5 & 83.0 & 18.8 & 18.3 & 40.4 \\
\hline & $\mathrm{Zn}$ & 100.5 & 182.9 & 73.2 & 6.6 & 459.8 \\
\hline & $\mathrm{Fe}$ & 4880.1 & 8896.3 & 1098.8 & 286.9 & 2984.6 \\
\hline & $\mathrm{Pb}$ & 17.1 & 30.8 & 4.7 & $<0.1$ & 1.6 \\
\hline & $\mathrm{Cr}$ & 32.0 & 58.7 & 72.5 & 0.0 & 11.7 \\
\hline & $\mathrm{Ni}$ & 9.6 & 17.6 & 24.7 & $<0.1$ & 2.8 \\
\hline & $\mathrm{Tl}$ & $<0.1$ & $<0.1$ & $<0.1$ & 0.0 & 0.0 \\
\hline
\end{tabular}

$11{ }^{\mathrm{a}}$ Dry basis 


\section{1}

2

3 Conventional pyrolysis was performed at two different temperatures (400 and $800{ }^{\circ} \mathrm{C}$ )

4 in the electric furnace (EF) shown in Fig. 2a. Approximately $4 \mathrm{~g}$ of sample was

5 introduced into a quartz reactor. First, the reactor was placed outside the EF and was

6 purged with $\mathrm{N}_{2}$ for 30 minutes at a flow rate of $50 \mathrm{~mL}_{\mathrm{STP}} \min ^{-1}$ to ensure an oxygen-free

7 atmosphere. Meanwhile, the EF was heated up to the pyrolysis temperature. Once the

8 reactor had been purged and the EF had reached the desired temperature, the $\mathrm{N}_{2}$ flow

9 was reduced to $10 \mathrm{~mL}_{\mathrm{STP}} \mathrm{min}^{-1}$ and the reactor was introduced into the $\mathrm{EF}$ for pyrolysis,

10 the duration of which was 1 hour. The gases evolved during pyrolysis were forced to

11 pass through a condensing system (cooled by a cryogenic solution of water and $\mathrm{NaCl}$ )

12 where the condensable compounds were removed from the gaseous fraction. Both the

13 reactor and the condensing system were weighed before and after the pyrolysis

14 experiment to determine the solid and liquid yields (respectively). The gas yield was

15 determined by difference. Then, the gaseous fraction was collected in a Tedlar® bag

16 and analysed by means of a Varian-CP3800 gas-chromatograph equipped with a TCD

17 detector and two columns connected in series. The first column was 80/100 Hayesep Q

$18(2 \mathrm{~m} \times 1 / 8$ in. $\mathrm{x} 2 \mathrm{~mm})$ and the second column was a 80/100 Molesieve $13 \mathrm{X}(1.5 \mathrm{~m} \times 1 / 8$

19 in. $\mathrm{x} 2 \mathrm{~mm}$ ). The second column was bypassed by a six-port valve for the analysis of the

$20 \mathrm{CO}_{2}$ and hydrocarbons. The carrier gas flow $(\mathrm{He})$ was $30 \mathrm{~mL} / \mathrm{min}$. The initial oven

21 temperature was set at $40^{\circ} \mathrm{C}$, which was maintained for $1.2 \mathrm{~min}$. It was then

22 programmed to rise from 40 to $65^{\circ} \mathrm{C}$ at $50{ }^{\circ} \mathrm{C} / \mathrm{min}$ with an isothermic step of $3.3 \mathrm{~min}$.

23 The temperature was then lowered from 65 to $55^{\circ} \mathrm{C}$ at $20^{\circ} \mathrm{C} / \mathrm{min}$ and held for $2.6 \mathrm{~min}$.

24 The injector and detector temperatures were fixed at $150^{\circ} \mathrm{C}$. The TCD was calibrated

25 using a standard gas mixture. 

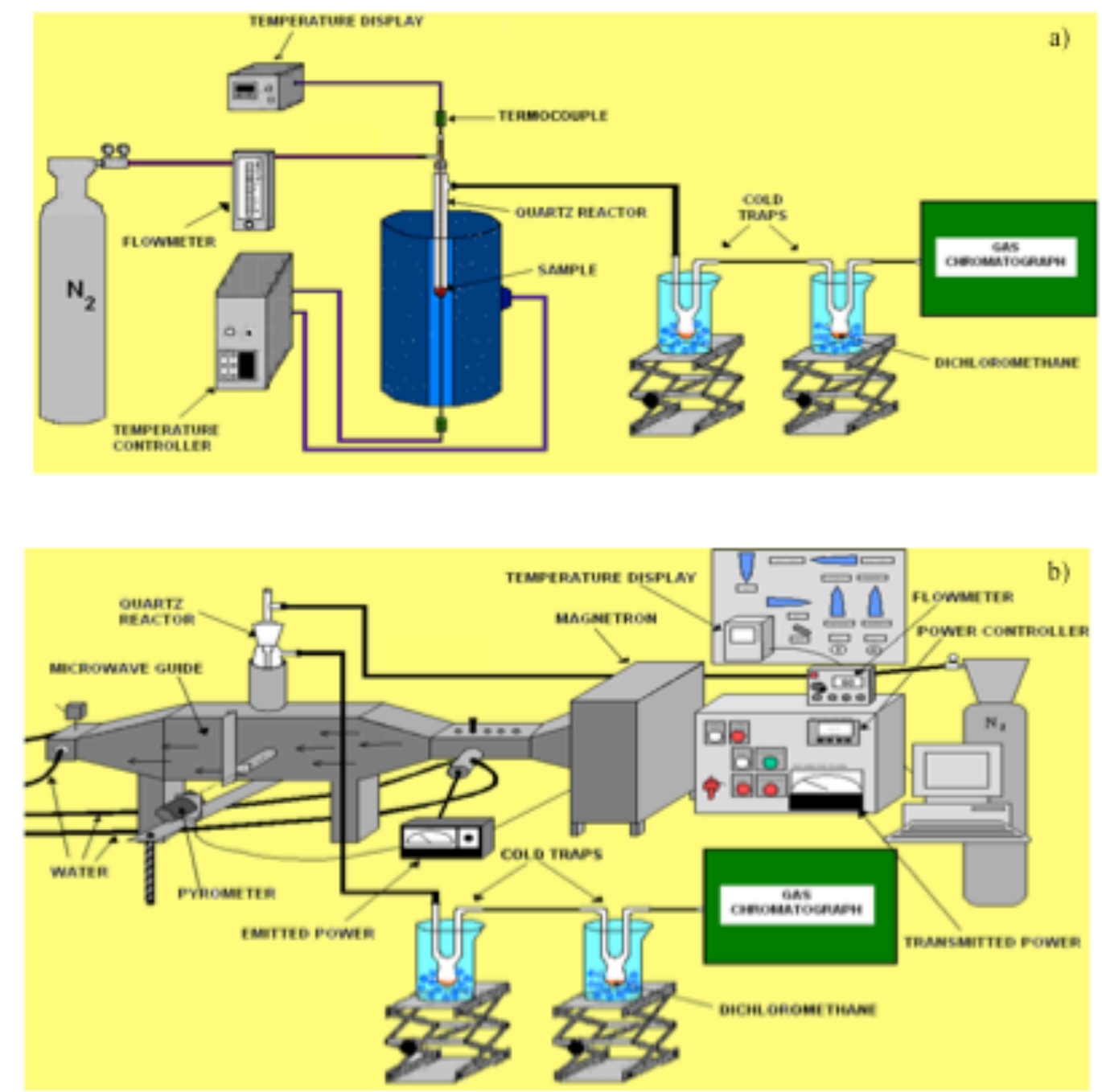

7 Microwave-induced pyrolysis (MIP) was performed using the microwave oven shown

8 in Fig. 2b. This system provided by MES (Microondes Énergie Systèmes) consists of a

9 microwave magnetron with a maximum output power of $2 \mathrm{~kW}$ operating at $2450 \mathrm{MHz}$

10 and a single mode cavity where the sample-containing quartz reactor was placed. As in

11 the conventional pyrolysis, the reactor was purged with $\mathrm{N}_{2}$ for 30 minutes at a flow rate 
1 of $50 \mathrm{~mL}_{\mathrm{STP}} \min ^{-1}$. Then, the flow rate was reduced to $10 \mathrm{~mL}_{\mathrm{STP}} \mathrm{min}^{-1}$ and the

2 microwave irradiation was switched on during $1 \mathrm{~h}$. The reflected power was regulated

3 by means of tuning screws until it reached zero. The same system as that used in

4 conventional pyrolysis, was used to collect the liquid and gaseous fractions.

5 Owing to the low capacity of organic wastes used in this study to absorb microwaves, it

6 was necessary to use a microwave receptor to induce the pyrolysis [27]. After the

7 microwaves started to pass through the sample, they are absorbed by the receptor and

8 the temperature increases. This allows the heat to be conducted to the waste until a

9 temperature high enough to start the pyrolysis is reached. As the pyrolysis proceeds, the

10 waste is carbonized and is then able to absorb microwaves, so that from that point on it

11 can be directly heated by microwave radiation. The most appropriate material for use as

12 microwave receptor is the char obtained from the previous pyrolysis, since it is a

13 product of the process itself and does not contain any strange material that might

14 influence the composition of the fractions. Nevertheless, other microwave receptor

15 materials, such as $\mathrm{SiC}, \mathrm{CaO}$ or activated carbons, could be used influencing pyrolysis

16 reactions [32]. For this study, a receptor - to - dry feedstock mass ratio of 0.3:1 was

17 selected. This ratio was selected after several preliminary experiments, which showed

18 that this was the lowest ratio that would allow the biomass to be heated to the desired

19 temperature while avoiding the thermal runaway effect which could result from

20 microwave heating [27]. The experiments were performed in duplicate to check the

21 repeatability. The errors came to less than $3 \%$ for the gas composition and less than $6 \%$

22 for the yields. 


\section{3. Results and Discussion}

2

$3 \quad 3.1$ Conventional vs. Microwave-induced pyrolysis

4

$5 \quad$ Fig.3 shows the specific yields from the three fractions obtained in the pyrolysis at 400

6 and $800{ }^{\circ} \mathrm{C}$ by conventional and microwave-induced pyrolysis. Some general trends can

7 be clearly observed, although they are more pronounced at $400{ }^{\circ} \mathrm{C}$ than at $800{ }^{\circ} \mathrm{C}$.

8

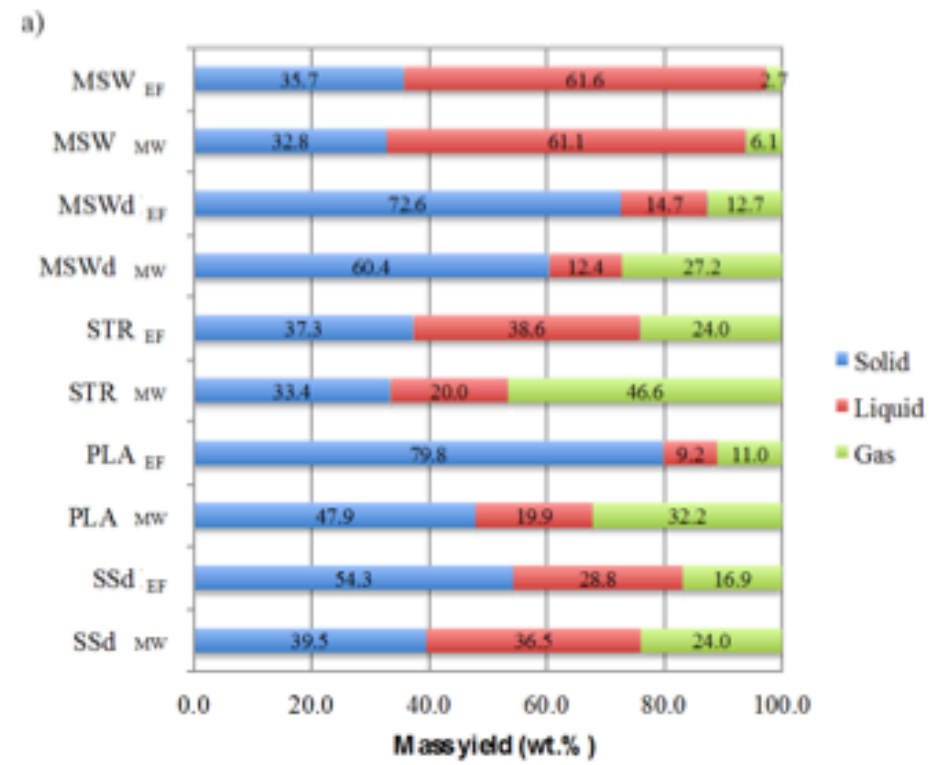

9

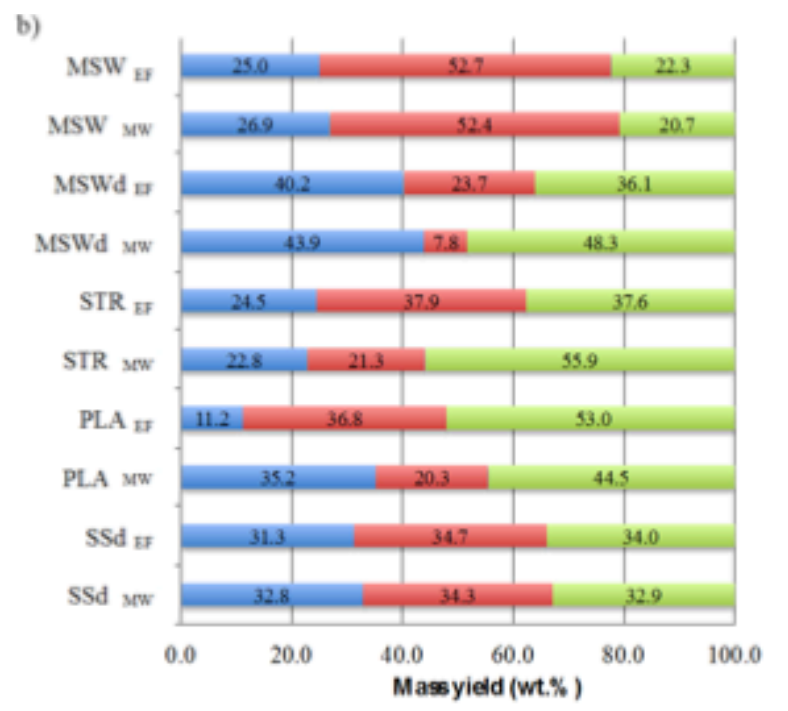

Fig. 3. Fraction yields (wt.\%) from the conventional (EF) and microwave-induced (MW) pyrolysis of the different residues at: (a) $400{ }^{\circ} \mathrm{C}$; and (b) $800{ }^{\circ} \mathrm{C}$. 
Table 3. Composition of the gaseous fraction (vol.\%) obtained in the conventional and microwave-induced pyrolysis of the different residues.

\begin{tabular}{|c|c|c|c|c|c|c|c|c|c|c|}
\hline & \multicolumn{5}{|c|}{ Conventional } & \multicolumn{5}{|c|}{ Microwave } \\
\hline & MSW & MSWd & PLA & STR & $\mathrm{SSd}$ & MSW & MSWd & PLA & STR & $\mathrm{SSd}$ \\
\hline $\mathrm{H}_{2}$ & 0.0 & 0.0 & 0.0 & 0.0 & 0.0 & 51.4 & 46.2 & 9.1 & 32.4 & 21.3 \\
\hline $\mathrm{CO}$ & 20.3 & 16.3 & 7.3 & 30.1 & 6.6 & 23.3 & 33.3 & 8.8 & 23.6 & 15.4 \\
\hline $\mathrm{CO}_{2}$ & 48.8 & 37.9 & 28.2 & 48.5 & 47.0 & 19.0 & 11.0 & 14.8 & 33.2 & 22.4 \\
\hline Syngas & 69.1 & 54.2 & 35.5 & 78.6 & 53.6 & 93.7 & 90.5 & 32.7 & 89.2 & 59.1 \\
\hline $\mathrm{CH}_{4}$ & 1.2 & 1.1 & 1.2 & 2.2 & 3.0 & 3.9 & 5.1 & 14.1 & 8.6 & 12.9 \\
\hline $\mathrm{C}_{2}$ & 1.0 & 0.7 & 3.2 & 0.9 & 1.7 & 2.4 & 4.4 & 23.8 & 2.3 & 8.1 \\
\hline Other* & 28.7 & 44.0 & 60.1 & 18.3 & 41.7 & 0.0 & 0.0 & 29.5 & 0.0 & 20.0 \\
\hline $\mathrm{H}_{2} / \mathrm{CO}$ & 0.00 & 0.00 & 0.00 & 0.00 & 0.00 & 2.21 & 1.39 & 1.03 & 1.37 & 1.38 \\
\hline $\mathrm{CO} / \mathrm{CO}_{2}$ & 0.42 & 0.43 & 0.26 & 0.62 & 0.14 & 1.23 & 3.03 & 0.59 & 0.71 & 0.69 \\
\hline
\end{tabular}

$800{ }^{\circ} \mathrm{C}$

\begin{tabular}{|c|c|c|c|c|c|c|c|c|c|c|}
\hline & \multicolumn{5}{|c|}{ Conventional } & \multicolumn{5}{|c|}{ Microwave } \\
\hline & MSW & MSWd & PLA & STR & $\mathrm{SSd}$ & MSW & MSWd & PLA & STR & $\mathrm{SSd}$ \\
\hline $\mathrm{H}_{2}$ & 22.4 & 21.4 & 9.2 & 19.8 & 15.8 & 47.6 & 50.4 & 26.6 & 49.1 & 48.2 \\
\hline $\mathrm{CO}$ & 24.3 & 25.6 & 9.6 & 31.1 & 18.1 & 33.7 & 36.2 & 11.5 & 37.4 & 22.6 \\
\hline $\mathrm{CO}_{2}$ & 23.9 & 25.5 & 11.3 & 28.9 & 17.6 & 13.6 & 8.0 & 8.1 & 8.7 & 15.2 \\
\hline Syngas & 70.6 & 72.5 & 30.1 & 79.8 & 51.5 & 94.9 & 94.6 & 46.2 & 95.2 & 86.0 \\
\hline $\mathrm{CH}_{4}$ & 11.2 & 12.7 & 20.3 & 13.0 & 20.7 & 3.1 & 3.3 & 20.0 & 3.7 & 8.1 \\
\hline $\mathrm{C}_{2}$ & 8.9 & 8.5 & 26.0 & 2.9 & 12.3 & 2.0 & 2.3 & 17.5 & 1.2 & 5.9 \\
\hline Other* & 9.2 & 6.3 & 23.7 & 4.2 & 14.4 & 0.0 & 0.0 & 16.3 & 0.0 & 0.0 \\
\hline $\mathrm{H}_{2} / \mathrm{CO}$ & 0.92 & 0.84 & 0.96 & 0.64 & 0.87 & 1.41 & 1.39 & 2.31 & 1.31 & 2.13 \\
\hline $\mathrm{CO} / \mathrm{CO}_{2}$ & 1.02 & 1.00 & 0.85 & 1.08 & 1.03 & 2.48 & 4.53 & 1.42 & 4.30 & 1.49 \\
\hline
\end{tabular}

* Higher hydrocarbons $\left(\mathrm{C}_{3}, \mathrm{C}_{4},>\mathrm{C}_{4}\right)$ and aromatics 
1 MIP enhances the gas production whereas the production of liquid is reduced in almost

2 all cases. At $400{ }^{\circ} \mathrm{C}$, MIP gives rise to greater gas yields than conventional pyrolysis.

3 These consist of a percent increase from $42 \%$ in the case of SSd to more than $100 \%$ in

4 the case of MSW and MSWd. The liquid yields are lower from MIP, with the exception

5 of SSd and PLA. These wastes contain a larger amount of volatiles that are released at

6 temperatures slightly higher than $400{ }^{\circ} \mathrm{C}$ compared to the other residues (see Fig. S1-S5

7 of ESI). Such volatiles can be removed from SSd and PLA by means of microwave

8 heating but not by conventional heating and hence the liquid yield is increased. This

9 ability of microwave heating to promote processes occurring at temperatures higher

10 than the operating temperature is due to the presence of microplasmas $[33,34]$. These

11 microplasmas are sparks or hot spots that last just a fraction of second and reach

12 temperatures considerably superior to the mean temperature of the material, which

13 remains at the operating temperature. However, temperature measurement of

14 microplasmas is a very complex issue, although this temperature must be high enough

15 to allow for such high $\mathrm{H}_{2}$ and $\mathrm{CO}$ concentrations observed in the gas fraction during

16 MIP as shown in Table 3. This phenomenon resembles what occurs in a lightning storm,

17 where the rays achieve an extremely high temperature without affecting the mean

18 temperature of the atmosphere. For this reason, microwave heating is able to extract

19 higher amounts of volatiles $[24,25,27]$. These volatiles are recovered in the liquid

20 fraction since temperatures are not high enough for further cracking into gaseous

21 products. In the case of the MSW, although there is a small decrease in liquid

22 production when microwave heating is used, the liquid yields are very similar in both

23 heating devices and considerably higher than in the other wastes. This is due to the high

24 moisture content, which mainly accumulates as water within the liquid fraction. Finally,

25 the solid yields are lower in the MIP than in the conventional pyrolysis in all the wastes 
1 [26]. As previously mentioned, the reason for this is that at $400{ }^{\circ} \mathrm{C}$ microwaves are able

2 to extract more volatiles than conventional heating, but cracking reactions are only

3 slightly promoted, as a result of which only a small amount of coke is produced (Table

44 , reactions 1 and 2).

5

6 Table 4. Main chemical reactions involved in pyrolysis.

7

\begin{tabular}{clc}
\hline Number & \multicolumn{1}{c}{ Reaction } & $\Delta \mathrm{H}_{298 \mathrm{~K}}\left(\mathrm{~kJ} \mathrm{~mol}^{-1}\right)$ \\
\hline 1 & $\mathrm{CH}_{4} \leftrightarrow \mathrm{C}+2 \mathrm{H}_{2}$ & 76 \\
2 & $\mathrm{C}_{\mathrm{n}} \mathrm{H}_{\mathrm{m}} \leftrightarrow \mathrm{n} \mathrm{C}+(\mathrm{m} / 2) \mathrm{H}_{2}$ & 136 \\
3 & $\mathrm{C}_{2} \mathrm{H}_{6} \leftrightarrow \mathrm{C}_{2} \mathrm{H}_{4}+\mathrm{H}_{2}$ & 247 \\
4 & $\mathrm{CH}_{4}+\mathrm{CO}_{2} \leftrightarrow 2 \mathrm{H}_{2}+2 \mathrm{CO}$ & 205 \\
5 & $\mathrm{CH}_{4}+\mathrm{H}_{2} \mathrm{O} \leftrightarrow 3 \mathrm{H}_{2}+\mathrm{CO}$ & \\
6 & $\mathrm{C}_{\mathrm{n}} \mathrm{H}_{\mathrm{m}}+\mathrm{n}_{2} \mathrm{O} \leftrightarrow \mathrm{n} \mathrm{CO}+(\mathrm{n}+\mathrm{m} / 2) \mathrm{H}_{2}$ & 173 \\
7 & $\mathrm{C}_{\mathrm{n}} \mathrm{H}_{\mathrm{m}}+\mathrm{n} \mathrm{CO}_{2} \leftrightarrow 2 \mathrm{n} \mathrm{CO}+(\mathrm{n} / 2) \mathrm{H}_{2}$ & 131 \\
8 & $\mathrm{C}+\mathrm{CO}_{2} \leftrightarrow 2 \mathrm{CO}$ & 90 \\
9 & $\mathrm{C}+\mathrm{H}_{2} \mathrm{O} \leftrightarrow \mathrm{CO}+\mathrm{H}_{2}$ & \\
10 & $\mathrm{C}+2 \mathrm{H}_{2} \mathrm{O} \leftrightarrow \mathrm{CO}_{2}+2 \mathrm{H}_{2}$ &
\end{tabular}

8

9 At $800{ }^{\circ} \mathrm{C}$, the differences between both heating devices are not as great and, in some 10 cases, the yields do not follow the same trends as in the experiments at $400{ }^{\circ} \mathrm{C}$. In the 11 case of the gas yields, some of the wastes show similar levels of gas production in both 12 devices (MSW and SSd), which may even be lower in the MIP than in conventional 13 pyrolysis (PLA). From the results in Table 3, it can be seen that in these cases (MSW, 14 SSd and PLA), the gases produced in the electric furnace have considerable amounts of 15 hydrocarbons $\left(\mathrm{CH}_{4}, \mathrm{C}_{2}\right.$ and $\left.>\mathrm{C}_{2}\right)$. These compounds, under microwave heating, can be 16 easily cracked into smaller hydrocarbons and coke (Table 4, reactions 1 and 2). Thus, a

17 large amount of the gases that are produced in the EF, especially from these

18 hydrocarbons, is deposited as coke, but to a much lesser extent than with microwave 
1 heating, which favors the formation of light gases (especially $\mathrm{H}_{2}$ and $\mathrm{CO}$ ). As a result,

2 coke production from these cracking reactions leads to higher solid yields. However, the

3 increase in the solid yield is also a consequence of the cracking of the liquid fraction

4 compounds, so that the liquid fraction yield decreases in all cases. Only MSW (due to

5 its high water content) and SSd show similar levels of liquid productions in MIP and

6 conventional pyrolysis (Fig. 3). However, it is important to bear in mind that these

7 yields are expressed in mass terms. Nevertheless, gas volumetric production (which

8 depends on the gas yield and composition) increases in the MIP regardless of the

9 residue and the temperature used.

11 The most remarkable differences between MIP and conventional pyrolysis are to be 12 seen in the composition of the gas fractions (Table 3). Conventional pyrolysis does not 13 produce $\mathrm{H}_{2}$ at low temperatures $\left(400{ }^{\circ} \mathrm{C}\right)$, whereas MIP is able to produce it in high 14 concentrations at both of the temperatures. Moreover, in conventional pyrolysis, the 15 maximum $\mathrm{H}_{2}$ concentration achieved is ca. $20 \%$ in the case of MSW and MSWd at 800 $16{ }^{\circ} \mathrm{C}$. In the case of MIP, the lowest $\mathrm{H}_{2}$ value achieved is slightly higher than $20 \%$, in the 17 pyrolysis of $\mathrm{SSd}$ at $400{ }^{\circ} \mathrm{C}$ (with the exception of PLA, which gave the worst results 18 irrespective of the temperature and heating device used to produce the syngas; being 19 this due to the nature of this substrate, which is mainly composed of polymeric carbon 20 chains with lower $\mathrm{H} / \mathrm{C}$ and $\mathrm{O} / \mathrm{C}$ molar ratios compared to the other residues). In terms 21 of syngas concentration (being the sum of $\mathrm{H}_{2}, \mathrm{CO}$ and $\mathrm{CO}_{2}$ concentrations, which are 22 the gases involved in fermentation processes), the results are even more favorable to 23 MIP. As can be seen, MIP gives rise to syngas concentrations above 90 vol.\% in many 24 cases, even at $400{ }^{\circ} \mathrm{C}$. Only in the case of plastics pyrolysis, is the syngas concentration 25 value really low for both heating devices (30-35\% in the case of conventional pyrolysis 
1 and 32-46\% in the case of MIP). Furthermore, owing to the high proportions of other

2 compounds $\left(\mathrm{CH}_{4}, \mathrm{C}_{2}\right.$, higher hydrocarbons and aromatics) which may damage the

3 bacteria and inhibit the fermentation process [35], the plastic fraction from municipal

4 solid waste can be discarded as substrate for this process. Here, MIP offers a significant

5 advantage over conventional pyrolysis, since it is able to minimize the presence of these

6 compounds within the gas fractions, which will favour a higher quality syngas available

7 for fermentation with the exception of using plastic waste.

8

9 The $\mathrm{H}_{2} / \mathrm{CO}$ and $\mathrm{CO} / \mathrm{CO}_{2}$ ratios of the gas fractions obtained are also shown in Table 3.

10 The values of these parameters reveal that MIP promotes the generation of $\mathrm{H}_{2}$ and $\mathrm{CO}$

11 over $\mathrm{CO}_{2}$. As can be seen, these ratios are higher in microwave heating than in

12 conventional heating.

14 Nevertheless, it is not only necessary to consider the composition of the gas fraction in 15 applying pyrolysis to bioplastics production via syngas fermentation [23], but also the 16 production of the key gases $\left(\mathrm{H}_{2}, \mathrm{CO}, \mathrm{CO}_{2}\right)$ for it is one of the parameters that

17 determines the effectiveness of these materials as substrates for the pyrolysis. The

18 results of the specific productions $\left(\mathrm{L}_{\mathrm{STP}} \mathrm{g}^{-1}\right.$ of residue pyrolysed) of $\mathrm{H}_{2}, \mathrm{CO}, \mathrm{CO}_{2}$, syngas

19 and total gas (including all the gaseous compounds) are shown in Table 5. As

20 mentioned above, the volumetric production of gas in MIP is higher than in

21 conventional pyrolysis in all cases. This is due to the fact that MIP favors the

22 production of lighter gases, such as $\mathrm{H}_{2}$ and $\mathrm{CO}$, due to cracking reactions,

23 dehydrogenating reactions (Table 4, reaction 3), reforming reactions (Table 4, reactions

24 4-7) and gasification processes (Table 4, reactions 8-10), where $\mathrm{CH}_{4}, \mathrm{CO}_{2}$, the

25 carbonaceous matter and steam are converted to lighter products. As already mentioned, 
1 the differences between MIP and conventional heating are apparent even at $400{ }^{\circ} \mathrm{C}$, the

2 production of syngas in MIP being as much as ten times higher than in the case of

3 conventional heating. This is mainly due to the large amounts of $\mathrm{H}_{2}$ produced by means

4 of MIP, even at low temperatures. At $800^{\circ} \mathrm{C}$, the gap, although still wide, narrows, the

5 syngas production in MIP being between 75 and $180 \%$ higher than in conventional

6 heating.

7

8 In view of these results, it is clear that microwave-induced pyrolysis is a quite good

9 technique for generating syngas from wastes without the need of a gasifying agent, as

10 would be necessary in the case of other technologies such as gasification. This method

11 is bound to increase the production of the key gases necessary for syngas fermentation

$12\left(\mathrm{H}_{2}, \mathrm{CO}\right.$ and $\left.\mathrm{CO}_{2}\right)$ and PHA production. 
1 Table 5. $\mathrm{H}_{2}, \mathrm{CO}, \mathrm{CO}_{2}$, syngas and total gas productions (on a dry basis) in the conventional and microwave-induced pyrolysis of the different 2 residues.

\begin{tabular}{|c|c|c|c|c|c|c|c|c|c|c|c|}
\hline & & \multicolumn{10}{|c|}{$400{ }^{\circ} \mathrm{C}$} \\
\hline & & \multicolumn{5}{|c|}{ Conventional } & \multicolumn{5}{|c|}{ Microwave } \\
\hline & & MSW & MSWd & PLA & STR & $\mathrm{SSd}$ & MSW & MSWd & PLA & STR & $\mathrm{SSd}$ \\
\hline \multirow{5}{*}{$\begin{array}{l}\text { Productions } \\
\left(\mathrm{L}_{\mathrm{STP}} / \mathrm{g}_{\text {waste }}\right)\end{array}$} & $\mathrm{H}_{2}$ & 0.00 & 0.00 & 0.00 & 0.00 & 0.00 & 0.07 & 0.17 & 0.02 & 0.16 & 0.05 \\
\hline & $\mathrm{CO}$ & 0.00 & 0.01 & 0.00 & 0.05 & 0.01 & 0.03 & 0.12 & 0.02 & 0.11 & 0.03 \\
\hline & $\mathrm{CO}_{2}$ & 0.01 & 0.02 & 0.01 & 0.08 & 0.04 & 0.03 & 0.04 & 0.04 & 0.17 & 0.05 \\
\hline & Syngas & 0.01 & 0.03 & 0.02 & 0.13 & 0.04 & 0.13 & 0.33 & 0.09 & 0.44 & 0.13 \\
\hline & Total gas & 0.02 & 0.04 & 0.05 & 0.16 & 0.08 & 0.14 & 0.36 & 0.26 & 0.50 & 0.22 \\
\hline
\end{tabular}

$800{ }^{\circ} \mathrm{C}$

\begin{tabular}{|c|c|c|c|c|c|c|c|c|c|c|c|}
\hline & & \multicolumn{5}{|c|}{ Conventional } & \multicolumn{5}{|c|}{ Microwave } \\
\hline & & MSW & MSWd & PLA & STR & $\mathrm{SSd}$ & MSW & MSWd & PLA & STR & $\mathrm{SSd}$ \\
\hline \multirow{5}{*}{$\begin{array}{l}\text { Productions } \\
\left(\mathrm{L}_{\mathrm{STP}} / \mathrm{g}_{\text {waste }}\right)\end{array}$} & $\mathrm{H}_{2}$ & 0.08 & 0.07 & 0.04 & 0.07 & 0.05 & 0.23 & 0.34 & 0.13 & 0.43 & 0.21 \\
\hline & $\mathrm{CO}$ & 0.09 & 0.08 & 0.04 & 0.11 & 0.06 & 0.16 & 0.25 & 0.06 & 0.33 & 0.10 \\
\hline & $\mathrm{CO}_{2}$ & 0.09 & 0.08 & 0.05 & 0.10 & 0.05 & 0.07 & 0.05 & 0.04 & 0.08 & 0.07 \\
\hline & Syngas & 0.26 & 0.24 & 0.13 & 0.30 & 0.16 & 0.46 & 0.64 & 0.23 & 0.83 & 0.37 \\
\hline & Total gas & 0.36 & 0.32 & 0.43 & 0.40 & 0.31 & 0.48 & 0.68 & 0.50 & 0.88 & 0.43 \\
\hline
\end{tabular}




\subsection{Applicability of syngas to bioplastics production}

Great efforts are being made to metabolically engineer bacteria to produce a broad variety of bulk chemicals, bioplastics and biofuels $[36,37]$ and to extend the use of substrates in the area of R\&D bacterial fermentation. Researchers are strongly in favour of syngas fermentation for bioplastics production $[21,38]$, but to date very few studies on syngas-derived biopolymers have been published. It has been widely claimed that, even though biological catalysts use a wide range of syngas $\mathrm{H}_{2} / \mathrm{CO}$ ratios, they retain their product specificity [39]. Therefore, the syngas production process needs to be focused on the most effective means of conversion in terms of energy efficiency and production.

From the point of view of energy efficiency, it has been observed that the scaling-up of microwave-heated processes from lab to kilogram scale can be more energy efficient than conventionally heated systems $[30,40]$. In particular, high-temperature processing, such as pyrolysis, using powerful magnetrons over an optimized frequency range appears to be very promising. Indeed, Scandinavian Biofuel Company has already taken out a patent to perform microwave-induced pyrolysis on an industrial scale [41].

From the point of view of production, Fig. 4a evidences the superiority of MIP in terms of syngas yield, especially in the case of the STR and MSWd substrates, whose maximum values are 0.83 and $0.64 \mathrm{~L}_{\mathrm{STP}} \mathrm{g}^{-1}$ waste respectively. Moreover, MIP offers a wider variety since the conventional pyrolysis yields only range from 0.01 to $0.26 \mathrm{~L}_{\text {STP }}$ $\mathrm{g}^{-1}$ waste. Although conventional pyrolysis yields a syngas composition that is richer in carbon (i.e., low values of $\mathrm{H}_{2} /\left(\mathrm{CO}+\mathrm{CO}_{2}\right)$ ratio), it is important to note that the largest part is $\mathrm{CO}_{2}$, whereas $\mathrm{CO}$ is normally the preferred substrate for fermentation $[21,22,42]$. 
In this respect, MIP improves $\mathrm{CO}$ production and the $\mathrm{H}_{2} /\left(\mathrm{CO}+\mathrm{CO}_{2}\right)$ ratio may even get to be higher than 1 , so that the $\mathrm{H}_{2}$ production would be greater than that of carbon oxides, except in the case of STR. However, neither of the organic fractions from municipal solid waste (MSW and MSWd) produce more carbon substrate $\left(\mathrm{CO}+\mathrm{CO}_{2}\right)$ than $\mathrm{H}_{2}$ in MIP.

As can be seen from Fig. 4b, microwave pyrolysis offers a wider range of syngas compositions, although it is not possible to produce syngas with $\mathrm{H}_{2} / \mathrm{CO}$ ratios lower than 1 . If necessary, conventional pyrolysis can be employed despite the serious drawback of undesired compounds (hydrocarbons and aromatics). In fact, if $\mathrm{H}_{2} / \mathrm{CO}$ ratios greater than 1 are used for syngas fermentation, as in microwave-induced pyrolysis, an excess of hydrogen may be the result. This, however, is a highly valuable chemical that does not greatly affect the fermentation process. Indeed, in a study by $D o$ et al., Rhodospirillum rubrum was cultivated on syngas to produce PHA (with ratios of $\mathrm{H}_{2} / \mathrm{CO}=0.5$ and $\left.\mathrm{CO} / \mathrm{CO}_{2}=1.1\right)[22]$. This gas composition was based on a typical stream from an air-blown gasifier, and therefore had not been optimized for PHA production. $R$. rubrum metabolized $\mathrm{CO}$ as the only substrate and produced $\mathrm{H}_{2}$ via the biocatalytic water-gas shift reaction $\left(\mathrm{CO}+\mathrm{H}_{2} \mathrm{O} \quad \mathrm{CO}_{2}+\mathrm{H}_{2}\right)$ in addition to the $\mathrm{H}_{2}$ from the syngas fed to the bioreactor. However, this should be considered an advantage, as $\mathrm{H}_{2}$ produced by a biorefinery is a co-product that has a high market value [23].

In spite of the repeated calls in the literature for a syngas $\mathrm{H}_{2} / \mathrm{CO}$ ratio independent of biocatalytic processes, there is some controversy surrounding this issue. Heiskanen et al. studied the effect of the syngas composition on Butyribacterium methylotrophicum [43]. The addition of hydrogen was reported to increase the formation of useful chemicals, such as butyric acid from B. methylotrophicum. In their study, they used a 
mixture of $\mathrm{H}_{2} / \mathrm{CO} / \mathrm{CO}_{2}$ in ratios of $\mathrm{H}_{2} / \mathrm{CO}=1.1$ and $\mathrm{CO} / \mathrm{CO}_{2}=1.4$, and found that $B$. metylotrophicum preferentially uses most of the $\mathrm{CO}$ before consuming hydrogen as reported in another study with Eubacterium limosum [44]. This suggests that $\mathrm{CO}_{2}$ was not indispensable to the growth of bacteria on $\mathrm{CO}$, but increased the initial growth rates of B. metylotrophicum, and was converted to valuable organic products in the presence of $\mathrm{H}_{2}$ once the $\mathrm{CO}$ concentration reached a low enough level. Thus, the subsequent uptake of these gases should be taken into account when designing the fermentation process. In addition, Vega et al. reported the growth of Peptostreptococcus productus (strain U-1) on $\mathrm{CO}$ and $\mathrm{CO}_{2} / \mathrm{H}_{2}$ to produce acetate and found that its growth on $\mathrm{CO}_{2} / \mathrm{H}_{2}$ could not be sustained, but when $\mathrm{CO}_{2}$ and $\mathrm{H}_{2}$ were fed together with $\mathrm{CO}$, with the resulting change in $\mathrm{H}_{2} / \mathrm{CO}$ ratio, they contributed to the production of acetate [45]. This suggests that the composition of the syngas has an effect on the growth rate and on the products obtained from fermentation.

Whatever the case, $\mathrm{CO}$ is by far the most important carbon source from syngas to be used by bacteria [21] and, clearly, microwave-induced pyrolysis can provide the level of $\mathrm{CO}$ required by offering $\mathrm{CO} / \mathrm{CO}_{2}$ ratios from 0.6 to 4.5 , whereas conventional pyrolysis can only offer a range of 0.1 to 1.1 (Fig. 4b). Furthermore, as previously indicated, the use of microwaves allows the potential destruction of components that may be toxic to the bacteria. This is a very important advantage, since the need to remove these compounds prior to syngas use will increase the production costs that can be avoided with microwave-induced pyrolysis. 

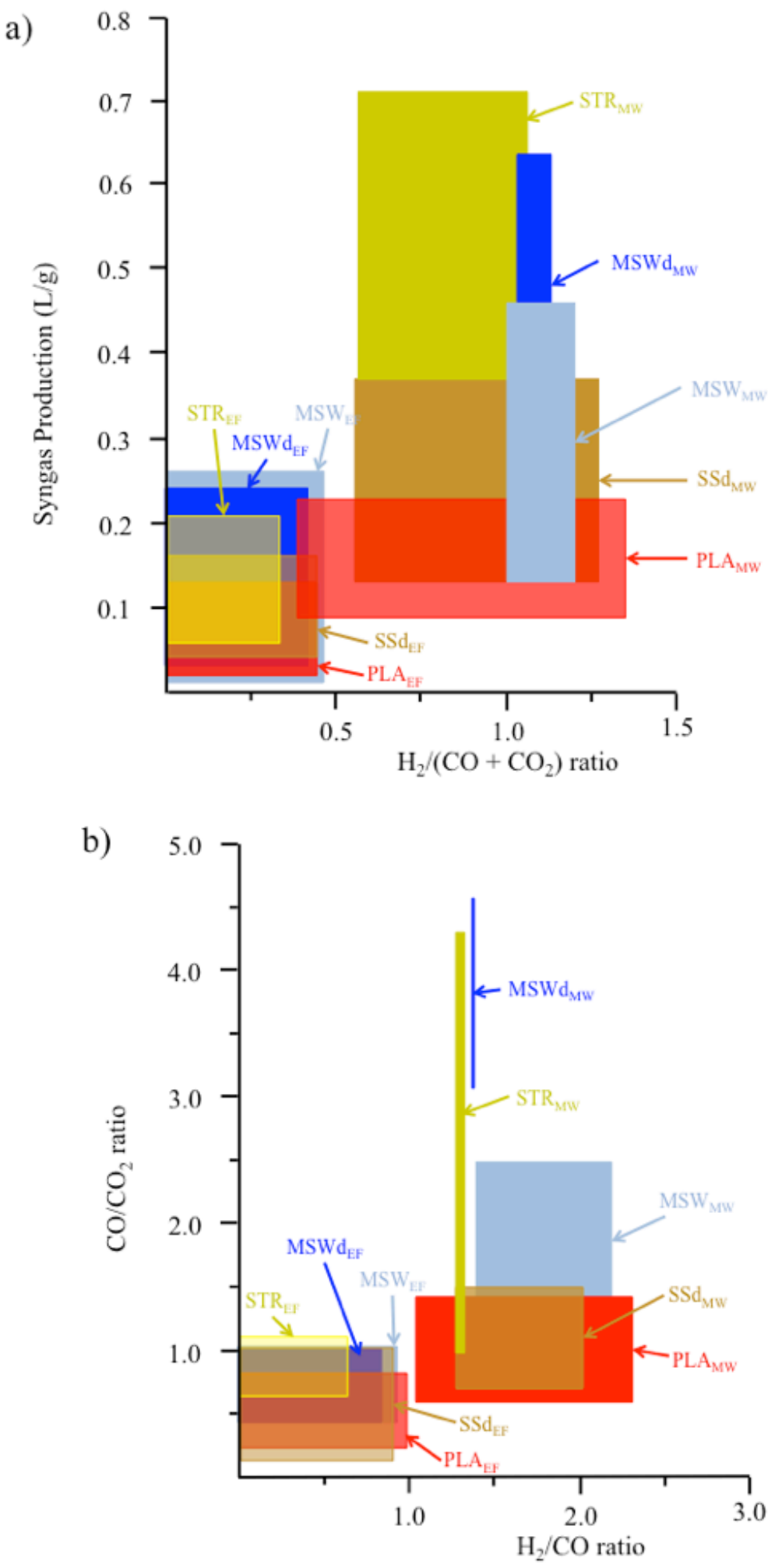

Fig. 4. (a) Syngas production versus $\mathrm{H}_{2} /\left(\mathrm{CO}+\mathrm{CO}_{2}\right)$ ratio and (b) $\mathrm{CO} / \mathrm{CO}_{2}$ ratio versus $\mathrm{H}_{2} / \mathrm{CO}$ ratio of the gas produced in the conventional (EF) and microwave-induced (MW) pyrolysis of the different wastes studied. 
Therefore, optimization of the syngas composition should be evaluated on a case-bycase basis by metabolic engineers for possible further bioplastics synthesis, bearing in mind that microwave-derived syngas offers overwhelming advantages over traditional methods of syngas production.

\section{Conclusions}

Syngas fermentation is attracting widespread interest for implementation in biorefineries and great efforts are being made to metabolically engineer microorganisms for the production of specifically targeted chemicals. Organic waste has been demonstrated to have the potential for producing a high quality syngas when microwave-induced pyrolysis is used as the main thermochemical route. $\mathrm{CO}$ has been found to be the main carbon substrate for fermentation by bacteria and the microwave heating to be the most efficient means of producing a syngas with high $\mathrm{CO} / \mathrm{CO}_{2}$ ratios, which are even greater than 4 when straw and the organic fraction of municipal solid waste (dried and partially cleaned of inert solids) are used. The plastics fraction of the municipal solid waste has been found to be unsuitable for syngas production, since its fossil-based nature leads to significant amounts of hydrocarbons and aromatics in the composition of the gas produced, which can be highly damaging to the bacteria. Except in this case, microwaves have been demonstrated to drastically reduce the hydrocarbons and aromatics content of the syngas produced. Furthermore, the gas obtained from microwave pyrolysis contains exceptionally high $\mathrm{H}_{2}$ concentrations, which amount to 49 vol.\% in the case of straw pyrolysis. This $\mathrm{H}_{2}$ could be used by bacteria as an energy source or remain as a valuable by-product for future use. To sum up, microwaveinduced pyrolysis has been confirmed to be a highly useful technology for producing 
syngas for use as in the production of bioplastics, due to its high gas production potential, high syngas concentration and low proportion of toxic compounds.

\section{Acknowledgments}

The research leading to these results has received funding from the European Union's Seventh Framework Programme for research, technological development and demonstration under grant agreement $n^{\circ} 311815$ (SYNPOL project). D. B. also acknowledges the support received from PCTI and FICYT of the Government of the Principado de Asturias. 


\section{References}

[1] S.M. Al-Salem, P. Lettieri and J. Baeyens, Recycling and recovery routes of plastic solid waste (PSW): A review, Waste Management. 29 (2009) 2625-2643.

[2] T. Bhaskar, T. Matsui, J. Kaneko, M.A. Uddin, A. Muto and Y. Sakata, Novel calcium based sorbent $(\mathrm{Ca}-\mathrm{C})$ for the dehalogenation $(\mathrm{Br}, \mathrm{Cl})$ process during halogenated mixed plastic (PP/PE/PS/PVC and HIPS-Br) pyrolysis, Green Chemistry. 4 (2002) 372-375.

[3] R.A. Sheldon, Green and sustainable manufacture of chemicals from biomass: state of the art, Green Chemistry (2014).

[4] M. Guo, D.C. Stuckey and R.J. Murphy, Is it possible to develop biopolymer production systems independent of fossil fuels? Case study in energy profiling of polyhydroxybutyrate-valerate (PHBV), Green Chemistry. 15 (2013) 706-717.

[5] T. Keshavarz and I. Roy, Polyhydroxyalkanoates: bioplastics with a green agenda, Current Opinion in Microbiology. 13 (2010) 321-326.

[6] C.S.K. Reddy, R. Ghai, Rashmi and V.C. Kalia, Polyhydroxyalkanoates: an overview, Bioresource Technology. 87 (2003) 137-146.

[7] S.A. Madbouly, J.A. Schrader, G. Srinivasan, K. Liu, K.G. McCabe, D. Grewell, W.R. Graves and M.R. Kessler, Biodegradation behavior of bacterial-based polyhydroxyalkanoate (PHA) and DDGS composites, Green Chemistry (2014).

[8] G.-Q. Chen and Q. Wu, The application of polyhydroxyalkanoates as tissue engineering materials, Biomaterials. 26 (2005) 6565-6578.

[9] S. Philip, T. Keshavarz and I. Roy, Polyhydroxyalkanoates: biodegradable polymers with a range of applications, Journal of Chemical Technology \& Biotechnology. 82 (2007) 233-247.

[10] K. Sudesh, H. Abe and Y. Doi, Synthesis, structure and properties of polyhydroxyalkanoates: biological polyesters, Progress in Polymer Science. 25 (2000) 1503-1555.

[11] C.-Y. Loo and K. Sudesh, Polyhydroxyalkanoates: bio-based microbial plastics and their properties, Malaysian Polymer Journal. 2 (2007) 31-57.

[12] L. Shen, J. Haufe and M.K. Patel, in Report for European Polysaccharide Network of Excellence (EPNOE) adn European Bioplastics, 2009, p. 243.

[13] Z.T. Dobroth, S. Hu, E.R. Coats and A.G. McDonald, Polyhydroxybutyrate synthesis on biodiesel wastewater using mixed microbial consortia, Bioresource Technology. 102 (2011) 3352-3359.

[14] I. Taniguchi, K. Kagotani and Y. Kimura, Microbial production of poly(hydroxyalkanoate)s from waste edible oils, Green Chemistry. 5 (2003) 545-548.

[15] Y. Jiang, L. Marang, J. Tamis, M.C.M. van Loosdrecht, H. Dijkman and R. Kleerebezem, Waste to resource: Converting paper mill wastewater to bioplastic, Water Research. 46 (2012) 5517-5530.

[16] F. Bosco and F. Chiampo, Production of polyhydroxyalcanoates (PHAs) using milk whey and dairy wastewater activated sludge: Production of bioplastics using dairy residues, Journal of Bioscience and Bioengineering. 109 (2010) 418421.

[17] D.W. Griffin and M.A. Schultz, Fuel and chemical products from biomass syngas: A comparison of gas fermentation to thermochemical conversion routes, Environmental Progress \& Sustainable Energy. 31 (2012) 219-224. 
[18] H. Younesi, G. Najafpour and A.R. Mohamed, Ethanol and acetate production from synthesis gas via fermentation processes using anaerobic bacterium, Clostridium ljungdahlii, Biochemical Engineering Journal. 27 (2005) 110-119.

[19] I.-S. Chang, B.-H. Kim, D.-H. Kim, R.W. Lovitt and H.-C. Sung, Formulation of defined media for carbon monoxide fermentation by Eubacterium limosum KIST612 and the growth characteristics of the bacterium, Journal of Bioscience and Bioengineering. 88 (1999) 682-685.

[20] P. Suriyamongkol, R. Weselake, S. Narine, M. Moloney and S. Shah, Biotechnological approaches for the production of polyhydroxyalkanoates in microorganisms and plants - A review, Biotechnology Advances. 25 (2007) 148-175.

[21] F.R. Bengelsdorf, M. Straub and P. Dürre, Bacterial synthesis gas (syngas) fermentation, Environmental Technology. 34 (2013) 1639-1651.

[22] Y.S. Do, J. Smeenk, K.M. Broer, C.J. Kisting, R. Brown, T.J. Heindel, T.A. Bobik and A.A. DiSpirito, Growth of Rhodospirillum rubrum on synthesis gas: Conversion of $\mathrm{CO}$ to $\mathrm{H} 2$ and poly- $\beta$-hydroxyalkanoate, Biotechnology and Bioengineering. 97 (2007) 279-286.

[23] D. Choi, D. Chipman, S. Bents and R. Brown, A Techno-economic Analysis of Polyhydroxyalkanoate and Hydrogen Production from Syngas Fermentation of Gasified Biomass, Applied Biochemistry and Biotechnology. 160 (2010) 10321046.

[24] A. Domínguez, Y. Fernández, B. Fidalgo, J.J. Pis and J.A. Menéndez, Biosyngas production with low concentrations of $\mathrm{CO} 2$ and $\mathrm{CH} 4$ from microwaveinduced pyrolysis of wet and dried sewage sludge, Chemosphere. 70 (2008) 397403.

[25] R. Luque, J.A. Menendez, A. Arenillas and J. Cot, Microwave-assisted pyrolysis of biomass feedstocks: the way forward?, Energy \& Environmental Science. 5 (2012) 5481-5488.

[26] J.A. Menéndez, A. Domínguez, M. Inguanzo and J.J. Pis, Microwave-induced drying, pyrolysis and gasification (MWDPG) of sewage sludge: Vitrification of the solid residue, Journal of Analytical and Applied Pyrolysis. 74 (2005) 406412.

[27] D. Beneroso, J.M. Bermúdez, A. Arenillas and J.A. Menéndez, Microwave pyrolysis of microalgae for high syngas production, Bioresource Technology. 144 (2013) 240-246.

[28] D. Beneroso, J.M. Bermúdez, A. Arenillas and J.A. Menéndez, Influence of the microwave absorbent and moisture content on the microwave pyrolysis of an organic municipal solid waste, Journal of Analytical and Applied Pyrolysis. 105 (2014) 234-240.

[29] X. Zhao, Z. Song, H. Liu, Z. Li, L. Li and C. Ma, Microwave pyrolysis of corn stalk bale: A promising method for direct utilization of large-sized biomass and syngas production, Journal of Analytical and Applied Pyrolysis. 89 (2010) 8794.

[30] V.L. Budarin, P.S. Shuttleworth, J.R. Dodson, A.J. Hunt, B. Lanigan, R. Marriott, K.J. Milkowski, A.J. Wilson, S.W. Breeden, J. Fan, E.H.K. Sin and J.H. Clark, Use of green chemical technologies in an integrated biorefinery, Energy \& Environmental Science. 4 (2011) 471-479.

[31] B. Kessler, R. Weusthuis, B. Witholt and G. Eggink, in W. Babel and A. Steinbüchel (Eds.), Biopolyesters, Springer Berlin Heidelberg, 2001, Chapter 5, p. 159-182. 
[32] Z. Hu, X. Ma and C. Chen, A study on experimental characteristic of microwave-assisted pyrolysis of microalgae, Bioresource Technology. 107 (2012) 487-493.

[33] J.A. Menéndez, E.J. Juárez-Pérez, E. Ruisánchez, J.M. Bermúdez and A. Arenillas, Ball lightning plasma and plasma arc formation during the microwave heating of carbons, Carbon. 49 (2011) 346-349.

[34] Y. Fernández and J.A. Menéndez, Influence of feed characteristics on the microwave-assisted pyrolysis used to produce syngas from biomass wastes, Journal of Analytical and Applied Pyrolysis. 91 (2011) 316-322.

[35] N. Nirmalakhandan, V. Arulgnanendran, M. Mohsin, B. Sun and F. Cadena, Toxicity of mixtures of organic chemicals to microorganisms, Water Research. 28 (1994) 543-551.

[36] B.P. Tracy, S.W. Jones, A.G. Fast, D.C. Indurthi and E.T. Papoutsakis, Clostridia: the importance of their exceptional substrate and metabolite diversity for biofuel and biorefinery applications, Current Opinion in Biotechnology. 23 (2012) 364-381.

[37] M. Mohammadi, G.D. Najafpour, H. Younesi, P. Lahijani, M.H. Uzir and A.R. Mohamed, Bioconversion of synthesis gas to second generation biofuels: A review, Renewable and Sustainable Energy Reviews. 15 (2011) 4255-4273.

[38] M. Köpke, C. Held, S. Hujer, H. Liesegang, A. Wiezer, A. Wollherr, A. Ehrenreich, W. Liebl, G. Gottschalk and P. Dürre, Clostridium ljungdahlii represents a microbial production platform based on syngas, Proceedings of the National Academy of Sciences (2010).

[39] R.C. Brown, Hybrid thermochemical/biological processing, Applied Biochemistry and Biotechnology. 137-140 (2007) 947-956.

[40] J.D. Moseley and C.O. Kappe, A critical assessment of the greenness and energy efficiency of microwave-assisted organic synthesis, Green Chemistry. 13 (2011) 794-806.

[41] K.I. Kasin, Microwave assisted flash pyrolysis system and method using the same, US20130032464 (2013).

[42] A.M. Henstra, J. Sipma, A. Rinzema and A.J.M. Stams, Microbiology of synthesis gas fermentation for biofuel production, Current Opinion in Biotechnology. 18 (2007) 200-206.

[43] H. Heiskanen, I. Virkajärvi and L. Viikari, The effect of syngas composition on the growth and product formation of Butyribacterium methylotrophicum, Enzyme and Microbial Technology. 41 (2007) 362-367.

[44] B.R. Sharak Genthner and M.P. Bryant, Growth of Eubacterium limosum with Carbon Monoxide as the Energy Source, Applied and Enviromental Microbiology. 43 (1982) 70-74.

[45] J. Vega, V. Holmberg, E. Clausen and J. Gaddy, Fermentation parameters of Peptostreptococcus productus on gaseous substrates (CO, H2/CO2), Archives of Microbiology. 151 (1988) 65-70.

[46] J.L. Vega, K.T. Klasson, D.E. Kimmel, E.C. Clausen and J.L. Gaddy, Sulfur gas tolerance and toxicity of co-utilizing and methanogenic bacteria, Applied Biochemistry and Biotechnology. 24-25 (1990) 329-340.

[47] A.J. Grethlein, B.K. Soni, R.M. Worden and M.K. Jain, Influence of hydrogen sulfide on the growth and metabolism ofbutyribacterium methylotrophicum andclostridium acetobutylicum, Applied Biochemistry and Biotechnology. 3435 (1992) 233-246. 
[48] K.T. Klasson, M.D. Ackerson, E.C. Clausen and J.L. Gaddy, Bioconversion of synthesis gas into liquid or gaseous fuels, Enzyme and Microbial Technology. 14 (1992) 602-608.

[49] M.D. Bredwell, P. Srivastava and R.M. Worden, Reactor Design Issues for Synthesis-Gas Fermentations, Biotechnology progress. 15 (1999) 834-844.

[50] R.M. Worden, M.D. Bredwell and A.J. Grethlein, in Fuels and Chemicals from Biomass, American Chemical Society, 1997, Chapter 18, p. 320-335.

[51] P.C. Munasinghe and S.K. Khanal, Biomass-derived syngas fermentation into biofuels: Opportunities and challenges, Bioresource Technology. 101 (2010) 5013-5022. 